\begin{tabular}{|c|c|c|}
\hline Iso 150 & $\begin{array}{c}\text { Bulletin of Pharmaceutical Sciences } \\
\text { Assiut University }\end{array}$ & \\
\hline 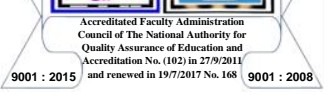 & $\begin{array}{c}\text { Website: http://bpsa.journals.ekb.eg/ } \\
\text { e-mail: bullpharm@aun.edu.eg }\end{array}$ & $\begin{array}{l}\text { BULL. PHARM. SCI. } \\
\text { Assiut Univ. }\end{array}$ \\
\hline
\end{tabular}

\title{
IN-VITRO INHIBITION OF TYPE 2 DIABETES KEY ENZYMES; EFFECT OF EXTRACTS AND SOLVENT-SOLVENT FRACTIONS OF DANIELLIA OLIVERI (ROLFE) HUTCH. \& DALZIEL
}

\author{
Sherif B Adeyemi*1,3, Vilas Surana ${ }^{2}$ and Ramar Krishnamurthy ${ }^{3}$ \\ ${ }^{1}$ Ethnobotany Unit, Department of Plant Biology, University of Ilorin, Ilorin, Nigeria \\ ${ }^{2}$ Maliba Pharmacy College, Uka Tarsadia University, Pin 394350, Surat District, Gujarat \\ State, India \\ ${ }^{3}$ C.G. Bhakta Institute of Biotechnology, Uka Tarsadia University, Pin 394350, Surat - \\ District, Gujarat State, India
}

\begin{abstract}
Daniellia oliveri is a tree species belonging to the subfamily Caesalpinioideae (Leguminosae), whose young leaves are used locally to manage type 2 diabetes in Nigeria. This study aims at evaluating the inhibitory potentials of its crude ethanolic extract (Do-C) and solvent-solvent fractions (n-hexane (Do-H), diethyl ether (Do-D), and ethyl acetate (Do-E)) obtained from Do-C on $\alpha$-amylase, $\alpha$-glucosidase activities in-vitro and 1,1-diphenyl-2picraylhydrazine (DPPH) radical scavenging activity using standard protocols. Our findings showed that the Do-C and its fractions had significant TFC and TPC composition. All fractions inhibited DPPH free radicals effectively, with Do-E having excellent inhibition when compared with BHT. In this study, Do-C and its solvent-solvent fractions (Do-D, Do-E, and Do-H) inhibited $\alpha$-amylase and $\alpha$-glucosidase in a dose-dependent pattern. However, compared to acarbose, the Do-E exhibited similar inhibitory activity against $\alpha$-amylase $(P \leq 0.05)$. Nevertheless, the Do-E (IC50 $35.02 \pm 1.22 \mu \mathrm{g} / \mathrm{ml})$ and Do-H (IC50 $31.28 \pm 1.23 \mu \mathrm{g} / \mathrm{ml})$ had the best inhibitory activity against $\alpha$-glucosidase comparatively after acarbose $(25.97 \pm 0.96$ $\mu \mathrm{g} / \mathrm{ml}$ ). The inhibitory potential of Do-E could be linked to its TFC and TPC. Therefore, ethyl acetate fraction obtained from the crude ethanolic extract of D. oliveri could effectively inhibit key enzymes linked to type 2 diabetes ( $\alpha$-amylase and $\alpha$-glucosidase). Further studies recommended to isolate antidiabetic compounds present.
\end{abstract}

\section{INTRODUCTION}

Hyperglycemia, or a high blood glucose level exemplified by a set of metabolic diseases, is caused by a defect in insulin secretion, action, or even both ${ }^{1 \& 2}$. Diabetes mellitus is a prevalent disease that the World Health Organization classifies as an epidemic ${ }^{3}$. Diabetes was categorised into four classes based on pathogenicity and not its treatment ${ }^{4}$. Type 1 and type 2 diabetes mellitus are widespread diabetic conditions. Other kinds of diabetes include gestational diabetes and diabetes associated with other disorders or drug use $^{2 \& 5}$. Type 1 diabetes mellitus (T1DM) is due to $\beta$-cell damage, which results in absolute insulin insufficiency and is mainly mediated by immunological processes ${ }^{6 \& 7}$. $\beta$-cell destruction prevents insulin release and reduces the rate of glucose absorption into muscles and adipose tissues $^{8}$.

Hyperglycemia caused by impaired insulin production, insulin action, and excessive glucagon secretion causes type 2 diabetes mellitus (T2DM), a chronic metabolic condition with life-threatening consequences $^{9,10}$. As documented, $90 \%$ of diabetes incidence worldwide is $\mathrm{T}_{2} \mathrm{DM}^{11}$. It is most prevalent in obese people and is linked to hypertension and dyslipidemia. The medication to manage the disease condition improves insulin sensitivity while also increasing insulin secretion $^{12}$. In 2015, it was projected that 415 million individuals globally had diabetes ${ }^{13}$, which grew to 451 million (age 18-99 years) in 2017, with about half of the cases 
undiagnosed $^{14}$. International Diabetes Foundation (IDF) reported that there were 463 million persons with diabetes globally in 2019 , with projections of 578 million by 2030 and 700 million by $2045^{11}$.

Natural $\alpha$-amylase and $\alpha$-glucosidase inhibitors derived from food-grade plants are commonly used to treat rise in blood sugar after the meal in type 2 diabetic patients ${ }^{15}$. $\alpha$ glucosidase inhibitors, viz; acarbose ${ }^{16}$, trestatin $^{17}$, and amylostatin ${ }^{18}$ isolated from microorganisms, were reported to regulate glucose uptake in the intestine. The use of these inhibitors, particularly acarbose, was associated with adverse consequences viz; stomach distention, flatulence, meteorism, and diarrhoea ${ }^{19 \& 20}$

Daniellia oliveri, commonly known as West African Copal tree, African copaiba balsam, Ilorin balsam, and Benin gum copal, is a member of the Caesalpinioideae subfamily (Family Leguminosae). Daniellia oliveri is the lone member of Daniellia subgenera Paradaniellia. The species "oliveri" is the Daniellia's most extensively dispersed species and are found throughout the lowland Savannah south of the Sahel ${ }^{21}$. Traditionally, the powdered dried leaf is administered orally to treat yellow fever and backache ${ }^{22}$. It has been documented that a decoction of $D$. oliveri roots and the root of Sarcocephalus latifolius is used as an antihyperglycemic treatment in southern Nigerian folk medicine ${ }^{23}$. Ringworm, scrotal elephantiasis, diarrhoea, syphilis, typhoid fever, and earache have been reportedly treated with the roots, stem barks, and leaves of D. oliveri ${ }^{24}$. In Nigeria, the young, tender leaves of $D$. oliveri are eaten ${ }^{25}$. The aqueous extract of the leaves was reported to be a safe and efficient treatment for $\mathrm{T}_{2} \mathrm{DM}^{26}$.

Notwithstanding the increasing usage of medicinal plants in most parts of the world as hypolipidemic $^{27}$ and hypoglycaemic agents $28 \& 29$ in managing chronic diabetes and its related complication, some medicinal plants are still understudied, one of which is $D$. oliveri. Various parts of $D$. oliveri have been reported in therapeutic applications. However, there is limited empirical information on using fresh young leaves to manage type 2 diabetes. Hence, our study investigates the in-vitro DPPH radical scavenging activity, $\alpha$-amylase, and $\alpha$ glucosidase inhibitory potential of the ethanolic crude extract of $D$. oliveri and its derived solvent-solvent fractions.

\section{MATERIALS AND METHOD}

\section{Reagents}

Folin-Ciocaltue reagent, 1,1-diphenyl-2picraylhydrazine (DPPH), Porcine Pancreatic $\alpha$-amylase, $\alpha$-glucosidase, 3,5-dintrosalicylic Acid (DNS), Acarbose, Butylated Hydroxytoluene (BHT), Ethanol, Diethyl ether, ethyl acetate, and n-hexane were products of SRL Pvt limited, India; $p$-Nitrophenyl- $\alpha$-Dglucopyranoside was a product of Hi-media. All buffers were prepared using standard procedures. All reagents were supplied locally by Dualife Science PVT limited, Kaveri Hebitet, Surat, India.

\section{Plant Materials Collection and Authentication}

The young leaves of Daniellia oliveri were collected from the natural habitat in the University of Ilorin, Ilorin, Nigeria. The plant was verified at species level in the Department of Plant Biology Herbarium, University of Ilorin, Nigeria. A voucher specimen was deposited for reference (UILH/001/1291/2021).

\section{Preparation of Extracts}

The leaves were sorted to make sure that only the fresh ones were selected. The sorted leaves were thoroughly rinsed under running water to ensure debris and dust were thoroughly removed. The washed leaves were air-dried for 21 days and then powdered using an electric blender. $400 \mathrm{~g}$ of the powdered was extracted with $2000 \mathrm{ml}$ distilled ethanol using the cold maceration method. The resulting extract was filtered under vacuum using Whatman filter paper (No. 1). The extract was concentrated using a rotary evaporator and a water bath to eliminate all the solvents.

\section{Partitioning of the Crude Extract}

The solvent-solvent fractionation of the resulting crude extract from above was carried out using standard protocols ${ }^{30,31}$ with modifications in partitioning solvents (nhexane, Diethyl ether, and Ethyl acetate). The crude ethanolic extract was dissolved in water and stirred on a magnetic stirrer at $60^{\circ} \mathrm{C}$. The water-soluble fraction was separated and exhaustively extracted by a consecutive partition with $\mathrm{n}$-hexane $(200 \mathrm{ml} \times 3)$, diethyl ether $(200 \mathrm{ml} \times 3)$, and ethyl acetate $(200 \mathrm{ml} \times 3)$ using a separating funnel. The fractions obtained were evaporated to dryness and 
labelled Do-C (D. oliveri Ethanolic Crude extract), Do-D (Diethyl ether fraction of Do-C), Do-E (Ethyl Acetate fraction of Do-C), Do-H (n-Hexane fraction of Do-C).

\section{Qualitative Phytochemical Assessment}

The phytochemical assessment of the crude and the fractionated extracts was accomplished using established procedures ${ }^{32-35}$.

\section{In-vitro antioxidant activity of extracts of $D$. oliveri}

\section{Estimation of total flavonoid content (TFC)}

$1 \mathrm{ml}$ of Quercetin (reference standard) and extract solution (various concentrations) was taken in a test tube. $3 \mathrm{ml}$ methanol was added, along with $200 \mu \mathrm{l}$ of $10 \% \mathrm{AlCl} 3$ and $200 \mu \mathrm{l}$ of a $1 \mathrm{M}$ potassium acetate solution. After adding distilled $(5.6 \mathrm{ml})$ water to the reaction, the test tubes were incubated at room temperature to complete the reaction. The solution's absorbance was determined at $420 \mathrm{~nm}$ using a UV-visible spectrophotometer (Shimadzu UV1800) in comparison to a blank.

The TFC in the plant extract and fractions (mg/g quercetin equivalent) was estimated using the formula:

$$
\mathrm{C}=\frac{(\mathrm{c} \times \mathrm{V})}{\mathrm{M}}
$$

$\mathrm{C}=$ Total flavonoid contents, mg/g Quercetin equivalent $(\mathrm{QE})$

$\mathrm{c}=$ Quercetin concentration calculated from the calibration curve, $\mathrm{mg} / \mathrm{ml}$

$\mathrm{V}=$ Volume of extract, $\mathrm{ml}$

$\mathrm{M}=$ The weight of the plant extract used, gm.

\section{Estimation of total phenolic content (TPC)}

The modified method of Singleton et al., ${ }^{36}$ was used. $0.5 \mathrm{ml}$ of methanolic solution of the extracts/Gallic Acid, standard reference (10$200 \mu \mathrm{g} / \mathrm{ml}$ ) was mixed with $2.5 \mathrm{ml} 10 \%$ FCR and $2.5 \mathrm{ml} 7.5 \% \mathrm{NaHCO}_{3}$. The mixture was incubated for $45 \mathrm{~min}$. (at $45^{\circ} \mathrm{C}$ ). The absorbance was read at $765 \mathrm{~nm}$ with UVvisible Spectrophotometer (Shimadzu UV1800). The Gallic Acid Calibration curve was constructed by plotting the OD vs. concentrations.

The total phenolic contents in the plant extract in Gallic Acid Equivalent (GAE) was evaluated employing the formula;

$$
\mathrm{C}=\frac{(\mathrm{c} \times \mathrm{V})}{\mathrm{M}}
$$

$\mathrm{C}=$ Total Phenolic Content, mg/g Gallic Acid Equivalent (GAE)

$\mathrm{c}=$ Gallic acid concentration determined from the calibration curve, $\mathrm{mg} / \mathrm{ml}$

$\mathrm{V}=$ Volume of extract $(\mathrm{ml})$

$\mathrm{M}=$ Extract weight used (gm).

\section{Evaluation of DPPH radical scavenging activity}

The method of Shen et al. ${ }^{37}$ was employed with modifications. Varying concentrations of fractions/Standard ( $3 \mathrm{ml}$ in methanol) were dispensed with $1 \mathrm{ml} \mathrm{DPPH}(0.1 \mathrm{mM})$ in test tubes. After rapidly agitating the mixture, it was allowed to stand at room temperature for thirty minutes in the dark. A UV-visible spectrophotometer (Shimadzu UV-1800) was used to determine the absorbance at $517 \mathrm{~nm}$. As a standard, butylated hydroxyl toluene was used. The control was prepared similarly to the standard/fractions but with methanol instead of standard/fractions. The reaction mixture's reduced absorbance indicated increased free radical scavenging activity.

The ability to scavenge the DPPH radicals was expressed as \%Inhibition (\%I) using the formula;

$$
\% \mathrm{I}=\frac{\text { Abs control }- \text { Abs sample }}{\text { Abs control }} \times 100
$$

Additionally, the antioxidant activity of the extract was also reported as an $\mathrm{IC}_{50}$ value. The $\mathrm{IC}_{50}$ value was defined as the concentration needed to reduce DPPH radical production by $50 \%$, as determined by plotting inhibition percentage vs. extract concentration.

\section{In-vitro Alpha-amylase Inhibitory Assay}

Varying concentrations (100 $\mu 1$ of $2,4,8$, 10 and $15 \mu \mathrm{g} / \mathrm{ml}$ ) of Acarbose, Do-C, Do-D, Do-E, and Do-H were incubated with $200 \mu$ of $20 \mathrm{mM}$ of phosphate buffer ( $\mathrm{pH} 6.9$ with 6.7 $\mathrm{mM} \mathrm{NaCl}$ ) comprising alpha-amylase at $37^{\circ} \mathrm{C}$ for $20 \mathrm{~min}$. Then, $100 \mu \mathrm{l}(1 \%)$ starch solution prepared in $20 \mathrm{mM}$ phosphate buffer was added to the reaction mixture and incubated at $37^{\circ} \mathrm{C}$ for $10 \mathrm{~min}$. The reaction was stopped by adding $200 \mu \mathrm{l}$ of 3,5-dinitro salicylic acid (DNSA). The reaction mixture was placed in a water bath to boil for 5 minutes, after when it was set aside 
to cool to room temperature. The reaction mixture was diluted by adding water $(2.2 \mathrm{ml})$, and absorbance was read at $540 \mathrm{~nm}$ against the blank in spectrophotometer UV-VIS (Shimadzu UV-1800). The control, representing 100\% enzyme activity, was prepared similarly, without the extract/fractions ${ }^{38}$. The study was in triplicate, and the amylase inhibitory activity was expressed as percentage inhibition (\% Inhibition).

\section{\%Inhibition $=(\mathrm{Ac}-\mathrm{As}) / \mathrm{Ac} \times 100$}

Ac is the absorbance of the control, and As is the sample absorbance.

\section{In-vitro Alpha-Glucosidase Inhibitory Assay}

The inhibitory activity of alphaglucosidase was evaluated using a revised version of a previously reported approach ${ }^{39,40}$. To $100 \mu \mathrm{l}$ of $(2,4,8,10,15 \mu \mathrm{g} / \mathrm{ml})$ plant extract/fractions/Acarbose, $\quad 200 \quad \mu l \quad \alpha$ glucosidase was added and the mixture incubated at $37^{\circ} \mathrm{C}$ for $20 \mathrm{~min} .100 \mu 13 \mathrm{mM} \mathrm{p}$ nitrophenyl -Glucopyranoside (p-NPG) was added to the reaction mixture and incubated at $37^{\circ} \mathrm{C}$ for $10 \mathrm{~min}$. The reaction was ended by adding $2 \mathrm{ml} 0.1 \mathrm{M} \mathrm{Na}_{2} \mathrm{CO}_{3}$. The $\alpha$-glucosidase activity was read at $405 \mathrm{~nm}$ in a UV-VIS spectrophotometer (Shimadzu UV-1800) by measuring the quantity of $\alpha$-nitrophenol released from $p$-NPG.

The test was in triplicate, and the alphaglucosidase inhibitory activity was expressed as percentage inhibition (\% I).

$$
\mathrm{I} \%=(\mathrm{Ac}-\mathrm{As}) / \mathrm{Ac} \times 100
$$

Ac is the absorbance of the control, and As is the absorbance of the sample

\section{Statistical Analysis}

The data obtained were subjected to statistical analysis using IBM SPSS Statistics Software (Version 20) and GraphPad Prism 8. One-way analysis of variance (ANOVA) followed by Duncan multiple range tests (DMRT) was used for multiple comparisons at a $5 \%$ probability level $(P \leq 0.05)$.

\section{RESULTS AND DESCUSSION}

\section{Results}

\section{Phytochemical Analysis}

Table 1 summarises the qualitative phytochemical composition of the $D$. oliveri leaf extracts. Alkaloids, flavonoids, and Phenols are present in Do-C and its fractions. Only the ethyl acetate fraction (Do-E) contains cardiac glycoside.

Table 1: Qualitative Phytochemical Composition of Daniellia oliveri extract and fractions

\begin{tabular}{|l|c|c|c|c||}
\hline Phytochemicals & $\begin{array}{c}\text { Do- } \\
\text { C }\end{array}$ & $\begin{array}{c}\text { Do- } \\
\text { D }\end{array}$ & $\begin{array}{c}\text { Do- } \\
\text { E }\end{array}$ & $\begin{array}{c}\text { Do- } \\
\text { H }\end{array}$ \\
\hline Alkaloids & + & + & + & + \\
\hline Carbohydrate & - & - & - & - \\
\hline Flavonoids & + & + & + & + \\
\hline $\begin{array}{l}\text { Cardiac } \\
\text { Glycosides }\end{array}$ & - & - & + & - \\
\hline Phenols & + & + & + & + \\
\hline Saponins & + & - & + & + \\
\hline Tannins & + & - & + & + \\
\hline
\end{tabular}

Legend: + = Present; - = Absent

Do-C: Daniellia oliveri Ethanolic Crude extract; Do-D: Diethyl ether fraction of Do-C; Do-E: Ethyl Acetate fraction of Do-C; Do-H: n-Hexane fraction of Do-C.

\section{Antioxidant activity of extracts of Daniellia oliveri \\ Total flavonoid and total phenolic contents}

Figure 1 illustrates the TFC and TPC of the crude ethanolic extract (Do-C) and its fractions (Do-D, Do-E, and Do-H). However, Do-H had the highest total flavonoid content (TFC) $(134.22 \pm 1.18 \mathrm{mg} / \mathrm{g} \mathrm{QE})$, although it was not significantly different from Do-D (132.72 \pm $6.65 \mathrm{mg} / \mathrm{g}$ QE) at $P \leq 0.05$. However, the determined value for Do-E $(112.94 \pm 0.77 \mathrm{mg} / \mathrm{g}$ QE) is higher than the parent extract, Do-C $(79.22 \pm 2.44 \mathrm{mg} / \mathrm{g} \mathrm{QE})$, which has the lowest TFC. Meanwhile, Do-E's total phenolic content (TPC) $(211.55 \pm 5.48 \mathrm{mg} / \mathrm{g}$ GAE) was considerably higher and differed significantly from the other fractions examined $(P \leq 0.05)$. The lowest concentration was found in Do-H $(29.22 \pm 0.93 \mathrm{mg} / \mathrm{g} \mathrm{GAE})$. 


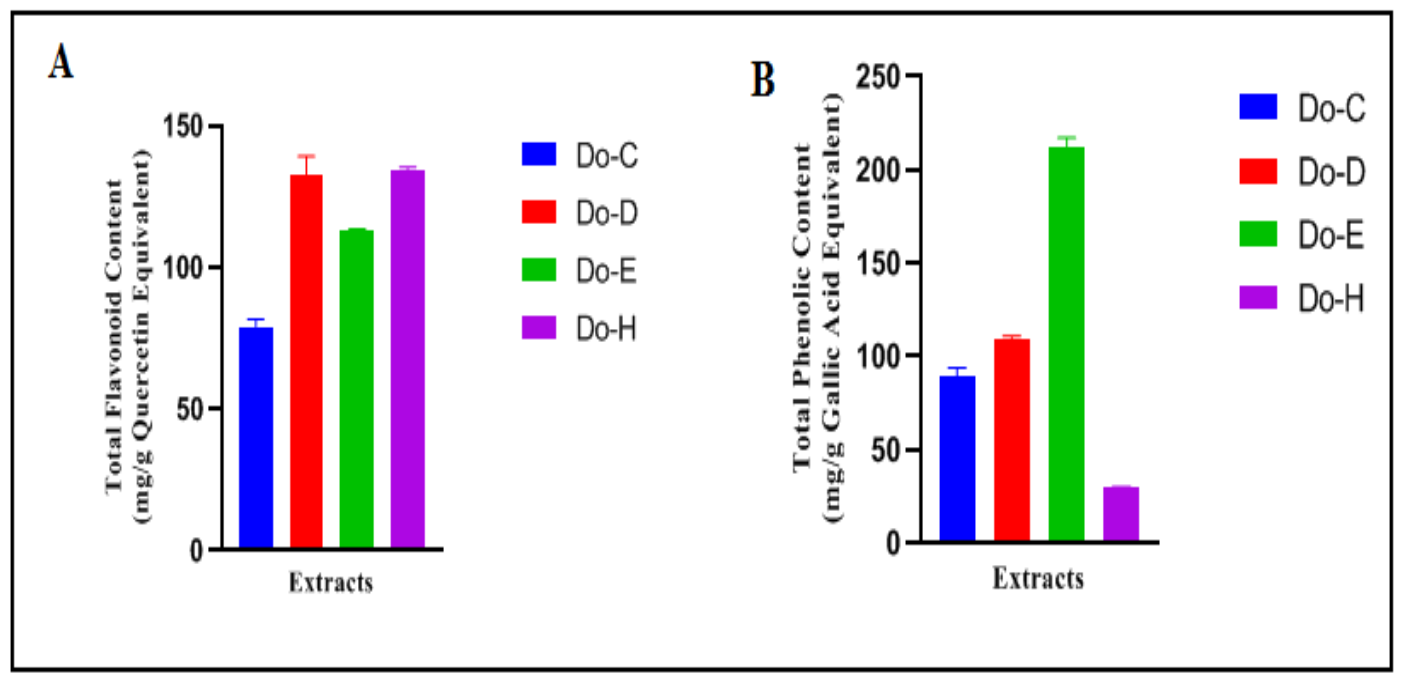

Fig. 1: Estimation of Antioxidant phytochemicals of extract and fractions of D. oliveri. (A) Total flavonoid content (mg/g Quercetin Equivalent); (B) Total Phenolic Content (mg/g Gallic Acid Equivalent); Do-C: Daniellia oliveri Ethanolic Crude extract; Do-D: Diethyl ether fraction of Do-C; Do-E: Ethyl Acetate fraction of Do-C; Do-H: n-Hexane fraction of Do-C. Values are mean of three replicates \pm Standard Error of Mean (SEM).

\section{DPPH radical scavenging activity}

In comparison to Butylated Hydroxytoluene (BHT), Do-C and its fractions (Do-D, Do-E, and Do-H) showed excellent DPPH scavenging activity (Table 2). The studied drugs had a dose-dependent pattern of activity. The lowest activity was found at $1 \mu \mathrm{g} / \mathrm{ml}$, whereas the maximum inhibition was reported at $100 \mathrm{~g} / \mathrm{ml}$. When compared to BHT $(98.46 \pm 0.44 \%)$, Do-D $(94.60 \pm 1.82 \%)$ and
Do-E $(93.06 \pm 0.59 \%)$ had a significantly the same effect in inhibiting DPPH radicals at $100 \mu \mathrm{g} / \mathrm{ml}$. Do-H had the lowest inhibition $(40.27 \pm 5.03 \%)$ at $100 \mathrm{~g} / \mathrm{ml}$. Except in Do-H, the mean effective concentration required to inhibit DPPH radical production by $50 \%$ was not significantly different $(P \leq 0.05)$. However, in all fractions examined, Do-E had the lowest $\mathrm{IC}_{50}(11.57 \pm 0.42 \mu \mathrm{g} / \mathrm{ml})$.

Table 2: DPPH Radical scavenging Activity of Fractions of Daniellia oliveri

\begin{tabular}{|l|c|c|c|c|c||}
\hline \multirow{2}{*}{$\begin{array}{c}\text { Concentration } \\
(\mu \mathrm{g} / \mathrm{ml})\end{array}$} & \multicolumn{5}{|c|}{ DPPH INHIBITION $\%$} \\
\cline { 2 - 6 } & BHT & Do-C & Do-D & Do-E & Do-H \\
\hline 1 & $14.11 \pm 4.72^{\mathrm{a}^{\mathrm{a}}}$ & $3.04 \pm 0.86^{\mathrm{bc}}$ & $10.27 \pm 1.09^{\mathrm{ab}}$ & $4.50 \pm 1.06^{\mathrm{bc}}$ & $0.00 \pm 0.00^{\mathrm{c}}$ \\
\hline 3 & $35.65 \pm 1.31^{\mathrm{a}}$ & $6.92 \pm 0.65^{\mathrm{b}}$ & $10.90 \pm 3.27^{\mathrm{b}}$ & $7.13 \pm 1.63^{\mathrm{b}}$ & $0.00 \pm 0.00^{\mathrm{c}}$ \\
\hline 5 & $60.06 \pm 1.66^{\mathrm{a}}$ & $13.63 \pm 0.75^{\mathrm{b}}$ & $16.66 \pm 4.72^{\mathrm{b}}$ & $17.93 \pm 5.42^{\mathrm{b}}$ & $2.51 \pm 0.83^{\mathrm{c}}$ \\
\hline 10 & $74.70 \pm 4.13^{\mathrm{a}}$ & $44.64 \pm 3.60^{\mathrm{b}}$ & $54.79 \pm 1.27^{\mathrm{b}}$ & $66.34 \pm 0.64^{\mathrm{a}}$ & $23.05 \pm 5.34^{\mathrm{c}}$ \\
\hline 20 & $91.78 \pm 0.93^{\mathrm{a}}$ & $49.13 \pm 4.17^{\mathrm{b}}$ & $53.76 \pm 4.59^{\mathrm{b}}$ & $75.98 \pm 2.24^{\mathrm{c}}$ & $16.38 \pm 4.91^{\mathrm{d}}$ \\
\hline 30 & $94.99 \pm 1.46^{\mathrm{a}}$ & $36.03 \pm 2.22^{\mathrm{b}}$ & $59.02 \pm 2.24^{\mathrm{c}}$ & $75.34 \pm 1.90^{\mathrm{d}}$ & $22.03 \pm 1.70^{\mathrm{e}}$ \\
\hline 50 & $92.04 \pm 1.34^{\mathrm{a}}$ & $46.82 \pm 9.42^{\mathrm{b}}$ & $70.71 \pm 3.09^{\mathrm{c}}$ & $82.79 \pm 0.13^{\mathrm{ac}}$ & $32.56 \pm 3.48^{\mathrm{b}}$ \\
\hline 100 & $98.46 \pm 0.44^{\mathrm{a}}$ & $76.11 \pm 2.32^{\mathrm{b}}$ & $94.60 \pm 1.82^{\mathrm{a}}$ & $93.06 \pm 0.59^{\mathrm{a}}$ & $40.27 \pm 5.03^{\mathrm{c}}$ \\
\hline IC50 $(\mu \mathrm{g} / \mathrm{ml})$ & $6.33 \pm 0.72^{\mathrm{a}}$ & $18.20 \pm 1.51^{\mathrm{a}}$ & $15.92 \pm 0.94^{\mathrm{a}}$ & $11.57 \pm 0.42^{\mathrm{a}}$ & $115.53 \pm 15.65^{\mathrm{b}}$ \\
\hline \hline
\end{tabular}

*Values are mean of three replicates \pm Standard Error of Mean (SEM)

Values with the same superscript across the rows are not significantly different $(\mathrm{P} \leq 0.05)$

Do-C: Daniellia oliveri Ethanolic Crude extract; Do-D: Diethyl ether fraction of Do-C; Do-E: Ethyl Acetate fraction of Do-C; Do-H: n-Hexane fraction of Do-C. Values are mean of three replicates \pm Standard Error of Mean (SEM) 
In-vitro $\alpha$-amylase and $\alpha$-glucosidase Inhibitory Assays

The observed inhibitory potential of the various fractions of $D$. oliveri against alphaamylase and alpha-glucosidase is dosedependent, as shown in figure $2(\mathrm{~A} \& \mathrm{~B})$. The standard drug, acarbose, exhibited remarkable inhibition as expected. In the alpha-amylase inhibition assay, the activity exhibited by Do-E was significantly at par with that of the standard drug but different from that of Do-D. The crude extract has the lowest inhibition percentage (Fig. 2A). The activity of the fractions in the alpha-glucosidase inhibitory assay followed the same pattern as in the alphaamylase inhibitory assay, except that Do-C exhibited more significant inhibition than Do-D (Fig. 2B).

The quantitative measures that indicate how much of the Do-C and its derived fractions needed to inhibit $\alpha$-amylase and $\alpha$-glucosidase by $50 \% \quad\left(\mathrm{IC}_{50}\right)$ were recorded (Table 3 ). Evaluating the $\mathrm{IC}_{50}$ values of alpha-amylase, the ethyl acetate fraction of Do-C (Do-E) exhibited the lowest $\mathrm{IC}_{50}(84.32 \pm 2.33 \mu \mathrm{g} / \mathrm{ml})$, and $\mathrm{IC}_{50}$ values of Do-C, Do-D, and Do-H were $147.56 \pm 5.30 \mu \mathrm{g} / \mathrm{ml}, 89.63 \pm 2.33 \mu \mathrm{g} / \mathrm{ml}$, and $115.66 \pm 4.60 \mu \mathrm{g} / \mathrm{ml}$, respectively. The $\mathrm{IC}_{50}$ of the standard drug, acarbose (77.84 \pm 1.09 $\mu \mathrm{g} / \mathrm{ml})$, was not distinct from Do-E $(P \leq 0.05)$. Meanwhile, Do-H exhibited the lowest $\mathrm{IC}_{50}$ $(31.23 \pm 1.23 \mu \mathrm{g} / \mathrm{ml})$ among the test fractions in $\alpha$-glucosidase inhibition assay, while it was not significantly different from the $\mathrm{IC}_{50}$ of Do-E $(35.02 \pm 1.22 \mu \mathrm{g} / \mathrm{ml})$ at $p \leq 0.05$. The $\mathrm{IC}_{50}$ for acarbose was $25.97 \pm 0.96 \mu \mathrm{g} / \mathrm{ml}$. The $\mathrm{IC}_{50}$ of acarbose, Do-E, and Do-H, on the other hand, did not differ significantly $(p \leq 0.05)$.

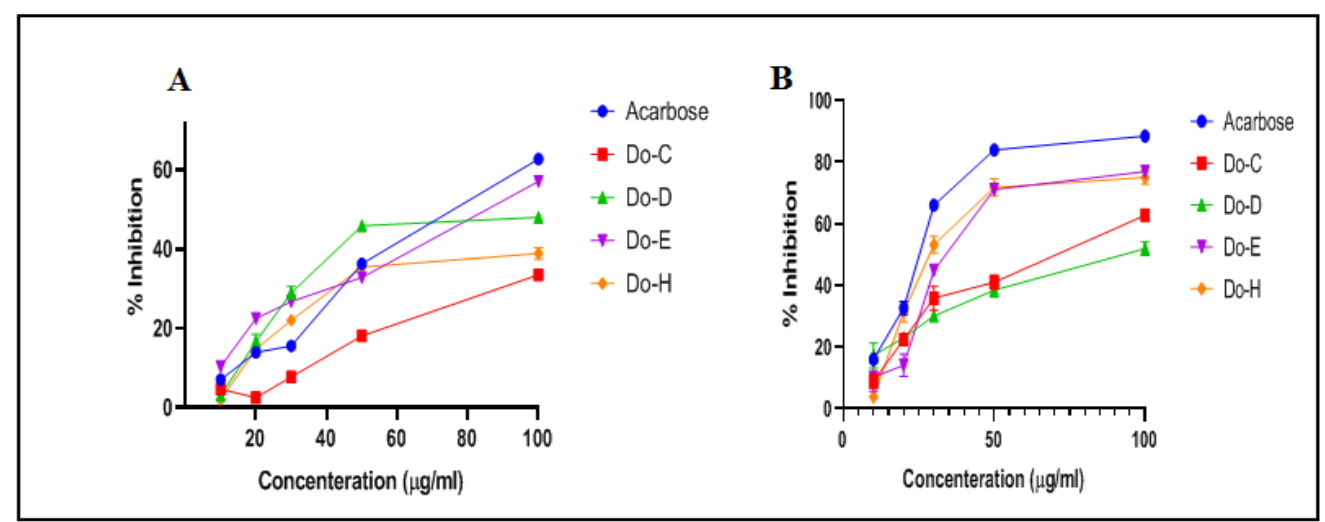

Fig. 2: In-vitro antidiabetic evaluations of extract and fractions of $D$. oliveri. $\alpha$-amylase inhibitory assay (A); $\alpha$-Glucosidase Inhibitory assay (B).

Do-C: Daniellia oliveri Ethanolic Crude extract; Do-D: Diethyl ether fraction of Do-C; Do-E: Ethyl Acetate fraction of Do-C; Do-H: n-Hexane fraction of Do-C. Values are mean of three replicates \pm Standard Error of Mean (SEM).

Table 3: In vitro Antidiabetic evaluations $\left(\mathrm{IC}_{50}\right)$ of Fractions of Ethanolic extract of Daniellia oliveri

\begin{tabular}{|c|c|c|}
\hline Extracts & $\begin{array}{c}\alpha \text {-amylase Inhibitory } \\
\text { Activity } \mathrm{IC}_{50}(\mu \mathrm{g} / \mathrm{ml})\end{array}$ & $\begin{array}{c}\alpha \text {-glucosidase Inhibitory Activity } \mathrm{IC}_{50} \\
(\mu \mathrm{g} / \mathrm{ml})\end{array}$ \\
\hline Standard $^{*}$ & $77.84 \pm 1.09^{\mathrm{*} *}$ & $25.97 \pm 0.96^{\mathrm{a}}$ \\
\hline Do-C & $147.56 \pm 5.30^{\mathrm{b}}$ & $64.98 \pm 8.10^{\mathrm{b}}$ \\
\hline Do-D & $89.63 \pm 2.33^{\mathrm{c}}$ & $89.28 \pm 11.26^{\mathrm{c}}$ \\
\hline Do-E & $84.32 \pm 2.33^{\mathrm{ac}}$ & $35.02 \pm 1.22^{\mathrm{a}}$ \\
\hline Do-H & $115.66 \pm 4.60^{\mathrm{d}}$ & $31.23 \pm 1.23^{\mathrm{a}}$ \\
\hline
\end{tabular}

*Standard: Acarbose for $\alpha$-amylase and $\alpha$-glucosidase inhibitory assays; Do-C: Daniellia oliveri Ethanolic Crude extract; Do-D: Diethyl ether fraction of Do-C; Do-E: Ethyl Acetate fraction of Do-C; Do-H: n-Hexane fraction of Do-C.

$* *$ Values are mean of three replicates \pm Standard Error of Mean (SEM)

Values with the same superscript down the column are not significantly different $(\mathrm{P} \leq 0.05)$ 


\section{Discussion}

Medicinal plants are rich in essential secondary metabolites that could be used to produce new therapeutic agents ${ }^{41}$. The secondary metabolites are critical contributors to the healing ability of medicinal plants and their derivatives ${ }^{42}$. Therefore, the solventsolvent partitioning of the ethanolic extract of $D$. oliveri leaf is a viable step in identifying potential antidiabetic chemicals.

The in-vitro antioxidant, alpha-amylase, and alpha-glucosidase activities of $D$. oliveri ethanolic extract and its solvent-solvent partitions, were remarkable. Several researchers have claimed that the phytochemicals found in these extracts have significant medicinal potential, particularly in treating diabetic mellitus ${ }^{43-48}$. It is worth noting that alkaloid was found in Do-C and its derived fractions (Do-D, Do-E, Do-H). Natural alkaloids have been reported to have potent inhibitory efficacy against carbohydrate-hydrolysing enzymes ${ }^{43}$. Alkaloids isolated from natural sources, especially medicinal plants, have been found to impede the actions of alpha-glucosidase enzymes and alpha-amylase enzymes ${ }^{44 \& 45}$. Alkaloids in Do-C and its fractions may be responsible for their therapeutic effect in inhibiting alpha-amylase and alpha-glucosidase enzymes.

Flavonoids observed in the crude ethanolic extract of $D$. oliveri leaf and its fractions, on the other hand, are antioxidants and free radical scavengers ${ }^{46,47}$. Flavonoids have been linked to medicinal plants' ability to regulate diabeticinduced oxidative stress $^{48}$. The in-silico insulin-mimetic activity of flavonoids is reportedly linked with a reduced risk of type 2 diabetes ${ }^{49 \& 50}$.

In diabetes, phenolic substances extracted from medicinal plants have been shown to limit the absorption of alpha-amylase ${ }^{45}$. According to Lin et al..$^{51}$, polyphenols, phenolic acids, and tannins are essential inhibitors of the alphaamylase and alpha-glucosidase enzymes. However, it has been observed that the presence of phenolics in plants aids in inhibiting digestive enzymes by attaching to them and altering their bioactivity ${ }^{52853}$ and serving as natural therapeutic intermediates in managing diabetes and its complications ${ }^{54}$. The tannins in Do-C and its fractions (Do-E and Do-H) may have the capacity to impede the activities of alpha-amylase and alphaglucosidase enzymes efficiently.
Cardiovascular disease is prone in people with reduced plasma antioxidants ${ }^{55}$. Thus, exogenous antioxidants are required for the balance of antioxidants and prooxidants in such people. Blois ${ }^{56}$ developed the DPPH inhibitory assay, which is frequently used to assess antioxidant activity and test the therapeutic efficacy of drugs as radical scavengers or hydrogen donors. The antioxidant efficacy of Do-C and its fractions in-vitro agrees with the report of Muanda, et al. ${ }^{57}$. Based on the exhibited antioxidant capacity $\left(\mathrm{IC}_{50}\right.$ of $15.49 \pm$ $0.39 \mu \mathrm{g} / \mathrm{ml}$ ), Atolani and Olatunji ${ }^{58}$ concluded that the oleoresin from $D$. oliveri could be a favourable source of natural antioxidants.

Inhibiting free radicals' generation is a therapeutic strategy for preventing oxidative stress and concomitant diabetic vascular problems $^{59}$. Free radical production that exceeds the scavenging capacity of endogenous antioxidants is also known to cause microvascular and macrovascular dysfunction and polyneuropathy ${ }^{60}$. As a result, in-vitro inhibition of DPPH scavenging radicals by our fractions implies that when administered invivo as an antidiabetic, they will effectively control diabetic complications.

In general, the $\alpha$-amylase enzyme digests carbohydrates by hydrolysing polysaccharide's 1,4-glycosidic bonds to disaccharides, which are then converted to monosaccharides by the $\alpha$-glucosidase enzyme. This process leads to postprandial hyperglycaemia ${ }^{61 \& 62}$. Do-C and its fractions are potent inhibitors of these enzymes, with Do-E displaying particularly strong inhibitions compared to acarbose. Their enzymes inhibition ability indicates that they can delay carbohydrate digestion, hence lowering postprandial glucose levels.

\section{Conclusion}

In the current investigation, Do-C and its solvent-solvent fractions (Do-D, Do-E, and Do$\mathrm{H})$ efficiently and effectively inhibited the primary carbohydrate-hydrolysing enzymes (alpha-amylase and alpha-glucosidase) linked to type 2 diabetes. However, further study is required to characterise the bioactive components responsible for the reported activity in this investigation. Furthermore, the toxicological consequences of utilising these fractions and the resulting isolated chemicals should be thoroughly investigated. 


\section{Acknowledgement}

Mr. E.B. Ajayi, the Department of Plant Biology Herbarium curator, was responsible for collecting and validating the plant samples utilised in this study. The authors are thankful to Uka Tarsadia University's administration for providing research support during the project. The administration of the University of Ilorin is commended for providing SBA with NEEDS assessment funds for the Ph.D. program.

\section{REFERENCE}

1. American Diabetes Association, "Diagnosis and classification of diabetes mellitus", Diabetes Care, 37(Suppl 1), 8190, (2014).

2. Z. Punthakee, R. Goldenberg and P. Katz, "Definition, classification and diagnosis of diabetes, prediabetes and metabolic syndrome", Can J Diabetes, 42(1), S10S15 (2018).

3. World Health Organization, "Definition, diagnosis and classification of diabetes mellitus and its complications: report of a WHO consultation", Geneva, World Health Organization Department of Noncommunicable Disease Surveillance, 1999.

4. J. D. F. Maraschin, "Classification of diabetes". In: Ahmad SI, Advances in Experimental Medicine and Biology: Vol 771. New York: Springer, 2013, pp. 12-19.

5. American Diabetes Association, "Classification and diagnosis of diabetes: Standards of Medical Care in Diabetes2020", Diabetes Care, 43(Suppl 1), 14-31, (2020).

6. R. Goldenberg and Z. Punthakee, "Definition, classification and diagnosis of diabetes, prediabetes and metabolic syndrome", Can J Diabetes, 37, 8-11 (2013).

7. W. Kerner and J. Brückel, "Definition, classification and diagnosis of diabetes mellitus", Exp Clin Endocrinol Diabetes, 122(07), 384-386, (2014).

8. A. L. Lehninger, D. L. Nelson and M. M. Cox, "Principles of Biochemistry", New York Worth, 1993.

9. Y. Lee, E. D. Berglund, M.-Y. Wang, X. $\mathrm{Fu}, \mathrm{X}, \mathrm{Yu}, \mathrm{M}$. J. Charron, S. C. Burgess and R. H. Unger, "Metabolic manifestations of insulin deficiency do not occur without glucagon action", Proc Natl Acad Sci, 109(37), 14972-14976, (2012).

10. H. Zaid, C. N. Antonescu, V. K. Randhawa and A. Klip, "Insulin action on glucose transporters through molecular switches, tracks and tethers", Biochem J, 413(2), 201-215, (2008).

11. International Diabetes Federation, "IDF Diabetes Atlas", IDF, 2019.

12. G. Arumugam, P. Manjula and N. Paari, "A review: Anti diabetic medicinal plants used for diabetes mellitus", J Acute Disease, 2(3), 196-200 (2013).

13. K. Ogurtsova, J. D. Da Rocha Fernandes, Y. Huang, U, Linnenkamp, L. Guariguata, N. H. Cho, D. Cavan, J. E. Shaw and L. E. Makaroff, "IDF Diabetes Atlas: Global estimates for the prevalence of diabetes for 2015 and 2040", Diabetes Res Clin Pract, 128, 40-50 (2017).

14. N. H. Cho, J. E. Shaw, S. Karuranga, Y. Huang, J. D. da Rocha Fernandes, A. W. Ohlrogge and B. Malanda, "IDF Diabetes Atlas: Global estimates of diabetes prevalence for 2017 and projections for 2045", Diabetes Res Clin Pract, 138, 271281 (2018).

15. Y. I. Kwon, E. Apostolidis, and K. Shetty, "Evaluation of pepper (Capsicum annuum) for management of diabetes and hypertension", J Food Biochem, 31(3), 370-385 (2007).

16. D. Schmidt, H. Former, B. Junge, M. Muller, W. Wingender, and E. Trusheit. "Alpha-Glucosidase inhibitors. New complex oligosaccharides of microbial origin", Naturwissenschaften, 64, 535-536 (1977).

17. K. Watanabe, T. Furumai, M. Sudoh, K. Yokose, and H. B. Maruyama, "New $\alpha-$ Amylase inhibitor, Trestatins IV. Taxonomy of the Producing Strains and Fermentation of Trestatin A", $\boldsymbol{J}$ Antibiotics, 37(5), 479-486, (1984).

18. S. Murao, K. Ohyama, and S. Ogura, "Isolation of amylase inhibitor-producing microorganism", Agric Biol Chem, 41(6), 919-924 (1977). 
19. H. Bishoff, W. Puls, H. Krause, H. Schutt, and G. Thomas, "Pharmacological properties of the novel glucosidase inhibitors BAY m 1099 (miglitol) and BAY o 1248", Diabetes Res Clin Pract, 1, 53-62 (1985).

20. W. Puls, U. Keup, H. Krause, P. Thomas, and F. Hoffmeister, "Glucosidase inhibition, A new approach to the treatment of diabetes, obesity, and hyperlipoproteinaemia",

Naturwissenschaften, 64, 536-537 (1977).

21. M. De La Estrella, C. Aedo, B. Mackinder, and M. Velayos, "Taxonomic Revision of Daniellia (Leguminosae: Caesalpinioideae)", Syst Bot, 35(2), 296324 (2010).

22. R. Bhat, E. Etejere, and V. Oladipo, "Ethnobotanical studies from central Nigeria", Econ Bot, 44(3), 382-390 (1990).

23. A. V. Iwueke and O. F. C. Nwodo, "Antihyperglycaemic effect of aqueous extract of Daniella oliveri and Sarcocephalus latifolius roots on key carbohydrate metabolic enzymes and glycogen in experimental diabetes", Biokemistri, 20(2), 63-70 (2008).

24. C. Nwaeze and P. Abarikwu, "Antimicrobial activity of certain medicinal plants used in traditional medicine in Nigeria", Nig $\boldsymbol{J}$ Mocrobiol, 6(12), 32-40 (2006).

25. O. M. Aboyade and D. R. Katerere, "Tribal and Indigenous Knowledge in West africa: the Use of Food plants in the Management of Diabetes", In: D. R. Katerere, A. Wendy, O. M. Aboyade and C. Togo. Traditional and Indigenous Knowledge for the Modern Era: A Natural and Applied Science Perspective, Boca Raton, FL, CRC Press, Taylor and Francis Group, 2019, pp. 43-71.

26. G. Shauibu, A. H. Abu, E. O. Agwu, V, Ehile, Z. E. Ezeudo, B. Ogedemgbe and S. Peter, "Effects of Daniella Oliveri Aqueous Leave Extract on Blood Glucose, Haematological and Biochemical Values in Streptozotocin-Induced Type 2 Diabetes in Male Albino Rats", Vom J Vet Sci, 13(1), 81-87 (2018).
27. J. Yadav, S. Saini, A. Kalia and A. Dangi, "Hypoglycemic and hypolipidemic activity of ethanolic extract of Salvadora oleoides in normal and alloxan-induced diabetic rats", Indian J Pharmacol, 40(1), 23-27 (2008).

28. M. Farswan, P. M. Mazumder and V. Percha,"Protective effect of Cassia glauca Linn. on the serum glucose and hepatic enzymes level in streptozotocin induced NIDDM in rats", Indian $\boldsymbol{J}$ Pharmacol, 41(1), 19-22 (2009).

29. A. Saidu, A. Mann and C. Onuegbu, "Phytochemical screening and hypoglycemic effect of aqueous Blighia sapida root bark extract on normoglycemic albino rats", Br J Pharm Res, 2(2), 89-97 (2012).

30. L. Zanatta, E. De Sousa, L. H. Cazarolli, A. C. Junior, M. G. Pizzolatti, B. Szpoganicz and F. R. M. B. Silva, "Effect of crude extract and fractions from Vitex megapotamica leaves on hyperglycemia in alloxan-diabetic rats", J Ethnopharmacol, 109(1), 151-155 (2007).

31. M. O. Egua, E. U. Etuk, S. O. Bello and S. W. Hassan, "Antidiabetic potential of liquid-liquid partition fractions of ethanolic seed extract of Corchorus olitorious", $\boldsymbol{J}$ Pharmacogn Phytother, 6(1), 4-9 (2014).

32. J. Harbone, "Phytochemical methods; A Guide to Modern Techniques of Plant Analysis", $2^{\text {nd }}$ edition, Chapman and Hall, London and New York, 1984.

33. W. C. Evans, G. E. Trease and D. Evans,"Trease and Evans' pharmacognosy", $15^{\text {th }}$ edition. W.B. Saunders, United Kingdom, 2002.

34. N. Raaman, "Phytochemical Techniques", New India Publishing Agency, Pitam Pura, New Delhi, 2006.

35. I. Gbadamosi, J. Moody and A. Yekini, "Nutritional composition of ten ethnobotanicals used for the treatment of anaemia in Southwest Nigeria", European J Med Plants, 2(2), 140-150 (2012).

36. V. L. Singleton, R. Orthofer and R. M. Lamuela-Raventós, "Analysis of total phenols and other oxidation substrates and antioxidants by means of folin-ciocalteu 
reagent", Meth Enzymol, 299, 152-178 (1999).

37. Q. Shen, B. Zhang, R. Xu, Y. Wang, X. Ding and P. Li, "Antioxidant activity in vitro of the selenium-contained protein from the Se-enriched Bifidobacterium animalis 01", Anaerobe, 16(4), 380-386 (2010)

38. H. Ali, P. Houghton and A. Soumyanath, " $\alpha$-Amylase inhibitory activity of some Malaysian plants used to treat diabetes; with particular reference to Phyllanthus amarus", J Ethnopharmacol, 107(3), 449455 (2006).

39. J.-S. Kim, T. K. Hyun and M.-J. Kim, "The inhibitory effects of ethanol extracts from sorghum, foxtail millet and proso millet on $\alpha$-glucosidase and $\alpha$-amylase activities", Food Chem, 124(4), 1647-1651 (2011).

40. L. J. Shai, P. Masoko, M. P. Mokgotho, S. R. Magano, A. M. Mogale, N. Boaduo and J. N. Ellof, "Yeast alpha glucosidase inhibitory and antioxidant activities of six medicinal plants collected in Phalaborwa, South Africa", S Afr J Bot, 76(3), 465-470 (2010).

41. S. Sahoo, G. Ghosh, D. Das and S. Nayak, "Phytochemical investigation and in vitro antioxidant activity of an indigenous medicinal plant Alpinia nigra BL Burtt", Asian Pac J Trop Biomed, 3(11), 871-876 (2013).

42. J. S. Negi, P. Singh and B. Rawat, "Chemical Constituents and Biological Importance of Swertia: a review", Curr Res Chem, 3(1), 1-15 (2011).

43. A. Kumar, S. Aswal, R. B. Semwal, A. Chauhan, S. K. Joshi and D. K. Semwal, "Role of plant-derived alkaloids against diabetes and diabetes-related complications: a mechanism-based approach", Phytochem Rev, 18(5), 12771298 (2019).

44. J. D. Wansi, J. Wandji, L. M. Meva'a, A. F. K. Waffo, R. Ranjit, S. N. Khan, A. Asma, C. M. Iqbal, M-C. Lallemand and F, Tillequin, " $\alpha$-Glucosidase inhibitory and antioxidant acridone alkaloids from the stem bark of Oriciopsis glaberrima E NGL. (Rutaceae)", Chem Pharm Bull, 54(3), 292-296 (2006).
45. P. M. Sales, P. M. Souza, L. A. Simeoni, P. O. Magalhães and D. Silveira, " $\alpha$-Amylase inhibitors: a review of raw material and isolated compounds from plant source", $\boldsymbol{J}$ Pharm Pharm Sci, 15(1), 141-183 (2012).

46. N. Salah, N. J. Miller, G. Paganga, L. Tijburg, G. P. Bolwell and C. Riceevans, "Polyphenolic flavanols as scavengers of aqueous phase radicals and as chainbreaking antioxidants", Arch Biochem Biophys, 322(2), 339-346 (1995).

47. O. Benavente-García, J. Castillo, F. R. Marin, A. Ortuño and J. A. Del Río, "Uses and properties of citrus flavonoids", $\boldsymbol{J}$ Agric Food Chem, 45(12), 4505-4515, (1997).

48. M. Yadav, S. Chatterji, S. K. Gupta and G. Watal, "Preliminary phytochemical screening of six medicinal plants used in traditional medicine", Int J Pharm Pharm Sci, 6(5), 539-542 (2014).

49. Y.-J. Liu, J. Zhan, X.-L. Liu, Y. Wang, J. Ji and Q.-Q. He, "Dietary flavonoids intake and risk of type 2 diabetes: a meta-analysis of prospective cohort studies", Clin Nutr, 33(1), 59-63 (2014).

50. H. Xu, J. Luo, J. Huang and Q. Wen, "Flavonoids intake and risk of type 2 diabetes mellitus: A meta-analysis of prospective cohort studies", Medicine, 97(19), 1-7 (2018).

51. D. Lin, M. Xiao, J. Zhao, Z. Li, B. Xing, $\mathrm{X}, \mathrm{Li}, \mathrm{M}$. Kong, L, Li, Q. Zhang and Y. Li, "An overview of plant phenolic compounds and their importance in human nutrition and management of type 2 diabetes", Molecules, 21(10), 1374 (2016).

52. S. Rohn, H. M. Rawel and J. Kroll, "Inhibitory effects of plant phenols on the activity of selected enzymes", J Agric Food Chem, 50(12), 3566-3571 (2002).

53. L. Mojica, A. Meyer, M. A. Berhow and E. G. De Mejía, "Bean cultivars (Phaseolus vulgaris L.) have similar high antioxidant capacity, in vitro inhibition of $\alpha$-amylase and $\alpha$-glucosidase while diverse phenolic composition and concentration", Food Res Int, 69, 38-48 (2015).

54. E. A. Irondi, G. Oboh, A. A. Akindahunsi, A. A. Boligon and M. L. Athayde, "Phenolic composition and inhibitory 
activity of Mangifera indica and Mucuna urens seeds extracts against key enzymes linked to the pathology and complications of type 2 diabetes", Asian Pac J Trop Biomed, 4(11), 903-910 (2014).

55. K. F. Gey, U. Moser, P. Jordan, H. Stähelin, M. Eichholzer and E. Lüdin, "Increased risk of cardiovascular disease at suboptimal plasma concentrations of essential antioxidants: an epidemiological update with special attention to carotene and vitamin C", Am J Clin Nutr, 57(5), 787S-797S (1993).

56. M. S. Blois, "Antioxidant determinations by the use of a stable free radical", Nature, 181(4617), 11991200 (1958).

57. F. Muanda, D. Koné, A. Dicko, R. Soulimani and C. Younos, "Phytochemical composition and antioxidant capacity of three malian medicinal plant parts", Evid Based Complement Alternat Med, 2011,1-8 (2011) .
58. O. Atolani and G. A. Olatunji, "Chemical composition, antioxidant and cytotoxicity potential of Daniellia oliveri (Rolfe) Hutch. \& Dalz", Turk J Pharm Sci, 13(1), 41-46 (2016).

59. S. Bajaj and A. Khan, "Antioxidants and diabetes", Indian J Endocrinol Metab, 16(Suppl 2), 267 (2012).

60. R. C. Ruhe and R. B. Mcdonald, "Use of antioxidant nutrients in the prevention and treatment of type 2 diabetes", J Am Coll Nutr, 20 (Suppl 5), 363S-369S (2001).

61. Y. Hara and M. Honda, "The inhibition of $\alpha$-amylase by tea polyphenols", $\boldsymbol{A g r}$ Biol Chem, 54(8), 1939-1945, (1990).

62. T. Matsui, T. Tanaka, S. Tamura, A. Toshima, K. Tamaya, Y. Miyata, K. Tanaka and K. Matsumoto, " $\alpha$ Glucosidase inhibitory profile of catechins and theaflavins", J Agric Food Chem, 55(1), 99-105 (2007). 


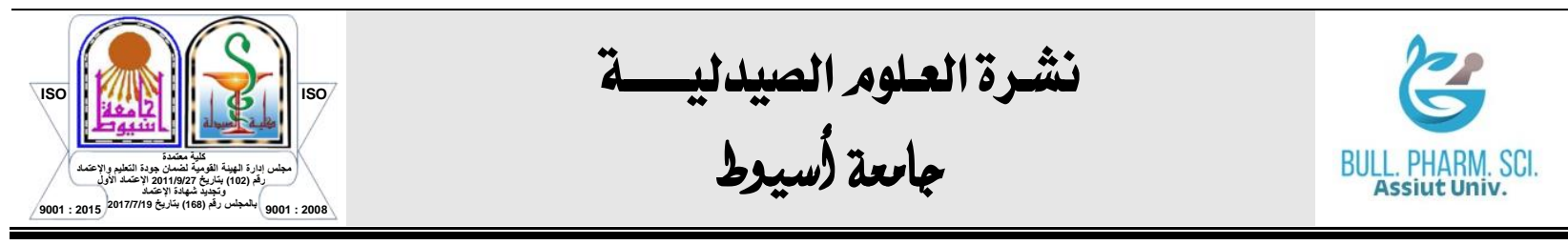

ثبيط إنزيمات رئيسية لمرض السكري من النوع الثاني في المختبر ؛ تأثير

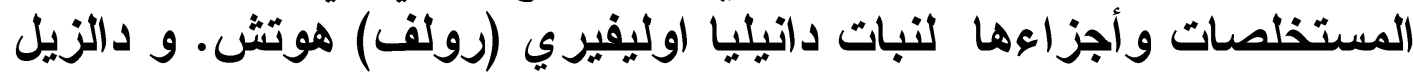
شريف ب أدييمي"ا، - فيلاس سورانا؟ - رامار كريشنامورثي"

'وحدة علم النبات العرقي ، قسم بيولوجيا النبات ، جامعة إيلورين ، إيلورين ، نيجيريا

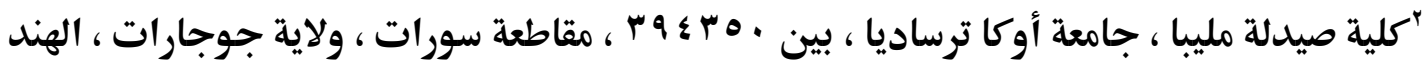

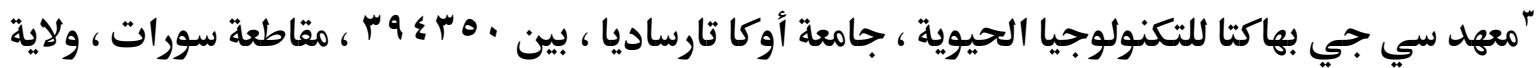
جوجارات ، الهند

نبات دانيليا اوليفيري هو نوع من الأشجار ينتمي إلى الفصيلة السيز البينودي (البقولية) ، و التي

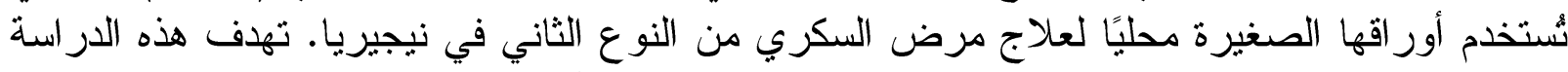

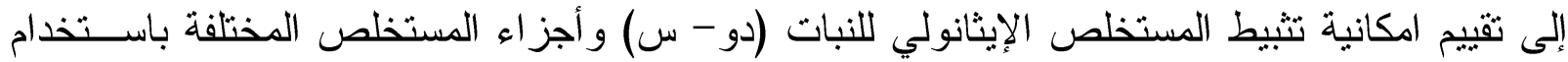

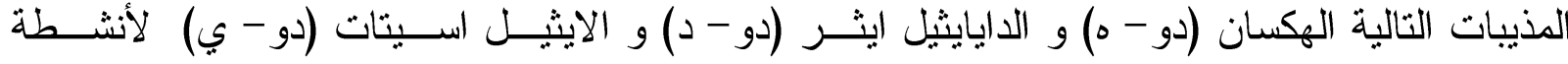

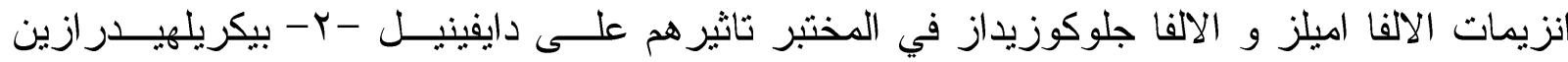

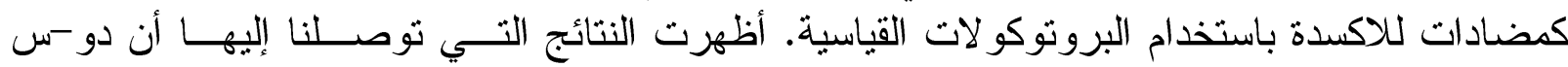

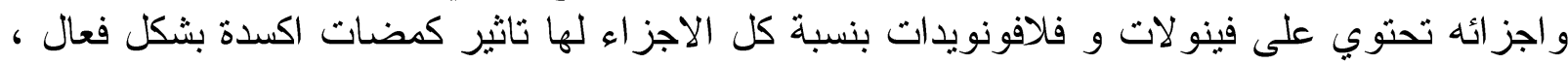

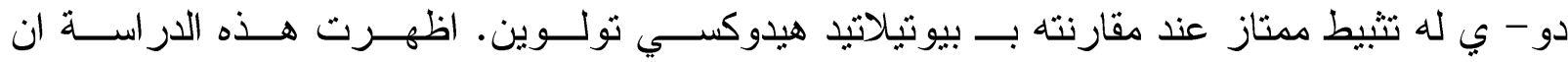

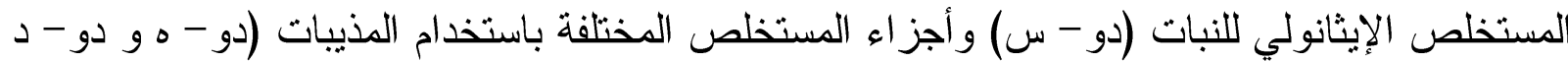

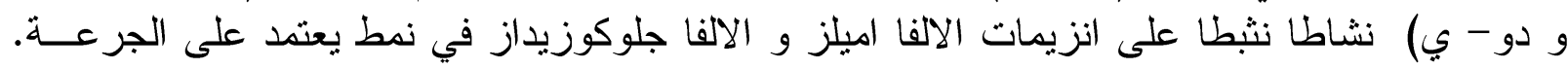

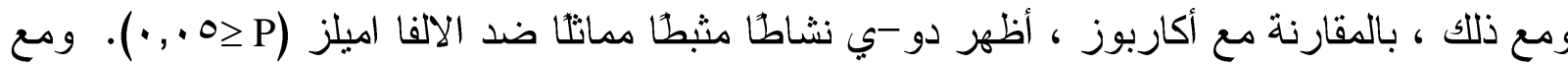

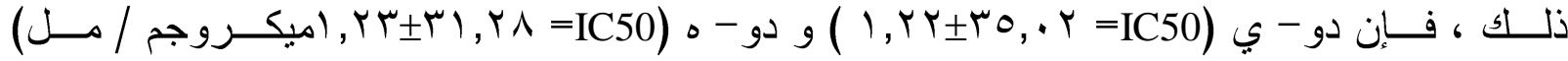

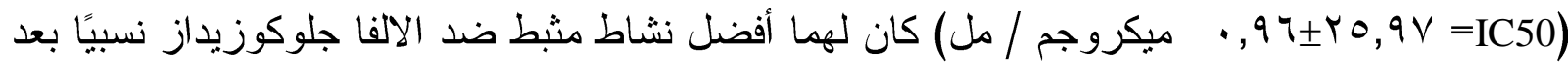
أكاربوز (Y0,9V

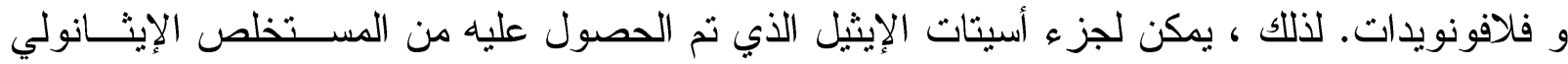

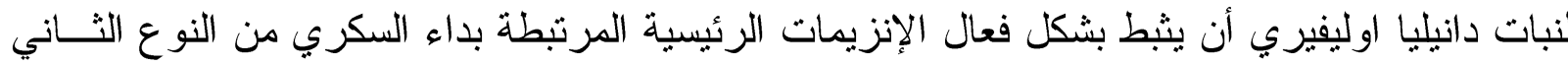

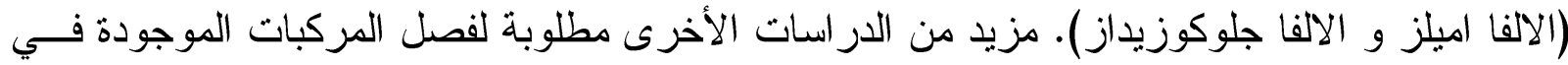
النبات و المعالجة لمرض السكري. 